\title{
Quality and antioxidant potential of 'BRS Magna' grapes harvested in the first half of the year under different training systems and rootstocks in a tropical region
}

\section{Qualidade e potencial antioxidante de uvas 'BRS Magna' colhidas no primeiro semestre do ano sob diferentes sistemas de condução e porta-enxertos em região tropical}

\author{
Talita de Oliveira Ferreira ${ }^{1}$, Rayssa Ribeiro da $\operatorname{Costa}^{2} \mathbb{D}$, Débora Tamara Félix ${ }^{3}$, \\ Eugenio Ribeiro de Andrade Neto ${ }^{4} \mathbb{D}$, Maísa de Macedo $\mathrm{Cruz}^{5} \mathbb{D}$, Maria Auxiliadora Coêlho de Lima ${ }^{*} \mathbb{E}^{\mathbb{D}}$ \\ 'Universidade Federal do Vale do São Francisco/UNIVASF, Programa de Pós-graduação em Produção Vegetal, Petrolina, PE, Brasil \\ ${ }^{2}$ Universidade Federal da Paraíba/UFPB, Programa de Pós-graduação em Agronomia, Areia, PB, Brasil \\ ${ }^{3}$ Universidade Federal de Sergipe/UFS, Programa de Pós-graduação em Ciência e Tecnologia de Alimentos, São Cristóvão, SE, Brasil \\ ${ }^{4}$ Universidade de Pernambuco/UPE, Petrolina, PE, Brasil \\ 5Universidade Federal Rural do Semi-Árido/UFERSA, Programa de Pós-graduação em Fitotecnia, Mossoró, RN, Brasil \\ ${ }^{6}$ Empresa Brasileira de Pesquisa Agropecuária, Embrapa Semiárido, Petrolina, PE, Brasil \\ ${ }^{*}$ Corresponding author: auxiliadora.lima@embrapa.br \\ Received in December 22, 2018 and approved in April 17, 2019
}

\begin{abstract}
The Submedium São Francisco Valley is renowned for its particular conditions for cultivating grapes for different uses. The production of grapes for juice is relatively recent, and thus, knowledge is still limited on components of the production system. The aim of this study was to characterize the quality and antioxidant activity of 'BRS Magna' grapes in irrigated crops of the Submedium São Francisco River Valley under the influence of training systems and rootstocks, in production cycles of the first half of the year. The experiment was conducted in the Experimental Field of Bebedouro/Embrapa Semiárido, in Petrolina, Pernambuco, Brazil. The following were studied: overhead trellis, lyre, and vertical shoot positioning (VSP) systems and rootstocks 'IAC 572' and 'IAC 766', in the production cycles corresponding to the first halves of 2017 and 2018. Experimental design was in randomized blocks, with sub-subplots through time and four replicates. Overall, responses depended on training systems, rootstocks, and production cycles, which determined specific traits of the grapes. Production in the first half of 2018 was characterized by high anthocyanin contents, high total extractable polyphenols, and higher antioxidant activity, and responses were differentiated according to training system and rootstock. Plants trained to overhead trellis and grafted on 'IAC 572' had higher accumulation of total extractable polyphenols and antioxidant activity in berries. Plants trained to VSP had increased sugar, yellow flavonoid, and anthocyanin contents in berries while lyre training system led to higher bunch mass.
\end{abstract}

Index Terms: Bioactive compounds; quality; hybrid grapes; grapes for juice.

\begin{abstract}
RESUMO
O Submédio do Vale do São Francisco é reconhecido pela particularidade das condições de produção de uvas para diferentes usos. A produção de uvas para suco nesta região é relativamente recente. Por isso, o conhecimento acerca dos componentes do sistema produtivo ainda é limitado. O objetivo deste trabalho foi caracterizar a qualidade e a atividade antioxidante da uva 'BRS Magna' sob influência de sistemas de condução e porta-enxertos, em ciclos produtivos do primeiro semestre do ano, em cultivo irrigado no Submédio do Vale do São Francisco. O experimento foi conduzido no Campo Experimental de Bebedouro/Embrapa Semiárido, em Petrolina, Pernambuco, Brasil. Foram estudados os sistemas de condução latada, lira e espaldeira e os porta-enxertos 'IAC 572' e 'IAC 766', nos ciclos produtivos correspondentes ao primeiro semestre dos anos de 2017 e 2018. O delineamento experimental foi em blocos ao acaso em parcelas subsubdivididas no tempo com quatro repetições. No geral, as respostas foram dependentes do sistema de condução, porta-enxerto e ciclo de produção, que determinaram características específicas às uvas. A produção no primeiro semestre de 2018 caracterizou-se por elevados teores de antocianinas e de polifenóis extraíveis totais e atividade antioxidante superior, sendo as respostas diferenciadas conforme o sistema de condução e o porta-enxerto. Plantas conduzidas em latada e enxertadas sobre 'IAC 572' tiveram maior acúmulo de polifenóis extraíveis totais e atividade antioxidante nas bagas. Sob espaldeira, foram observados incrementos nos teores de açúcares, flavonoides amarelos e antocianinas das bagas enquanto o sistema lira promoveu maior massa dos cachos.
\end{abstract}

Termos para indexação: Compostos bioativos; qualidade; uvas híbridas; uvas para suco. 


\section{INTRODUCTION}

Grapes are among the most produced crops worldwide. Aside from being cultivated for fresh fruit consumption, there has been increased interest in grape derivatives over the last years, especially grape juice (FAO-OIV, 2016). In Brazil, the use national cultivars for grape juice making has expanded as these cultivars adapt to the different climatic conditions in the country. The Submedium São Francisco River Valley, located in northeastern Brazil, stands out in the production of table grapes and wines. Grape juice production has gained prominence over this decade and its cultivated area is already larger than that of wine grapes.

Some cultivars have excellent adaptation to conditions in this region, e.g., 'Isabel Precoce', 'BRS Violeta', 'BRS Cora', and more recently, 'BRS Magna', released in 2012 by Embrapa Uva e Vinho. This cultivar has high contents of pigments, high sugar contents, and moderate acidity. With these characteristics, it is possible to elaborate an excellent quality juice with no need for blends (Ritschel et al., 2014).

Some studies have highlighted characteristics in juices made from 'BRS Magna' grapes, including basic components of quality, phenolic profile and contents, antioxidant activity and volatile organic compounds (Crucello et al., 2018; Lima et al., 2014; Mariani; Nava, 2018; Ristchel et al., 2014). Aspects of phenology, adaptation to different regions and yield performance have also been evaluated (Ritschel et al., 2014; Leão at al., 2018). Additionally, the cultivated areas are expanding despite the limited knowledge on management techniques, including production factors that provide higher agronomic performance.

Production components, along with grape juice processing techniques, are decisive factors to obtain a quality product. Among these factors, training systems and rootstocks affect the chemical composition of grapes. In the region of the Submedium São Francisco River Valley, the most frequently adopted training system for table grapes and juice is overhead trellis although there is no scientific recommendation for this. Other systems, such as vertical shoot positioning (VSP) and lyre, are used with grapes intended for wine making. Training systems are used to improve canopy management practices, fruit yield and quality, mostly because they change the intensity of grape exposure to sunlight and temperature inside the canopy, while responses such as changes in chemical composition and scion cultivar vigor have been attributed to rootstock (Bem et al., 2015;
Dias et al., 2017). Silva et al. (2018) mentioned high values of soluble solids and reducing sugars contents in Isabel Precoce, BRS Carmen, BRS Cora and IAC 138-22 Máximo grape cultivars that are recommended for juice making, when grapevines are grafted on IAC 766 rootstock.

Therefore, a proper combination of agricultural practices or techniques can promote a production system more competitive. In addition, the geographical origin and grape cultivar played a very important role in distinguishing Brazilian grape juices, as shown by Margraf et al. (2016) referring to differences on antioxidant activity and some chemical compounds.

Production season also accounts for differences in grape quality. Harvests in specific periods of the year, with their climatic particularities, might affect the quality of grapes and juices (Hunter; Bonnardot, 2011), either positively or negatively. Under tropical conditions, in the Submedium São Francisco River Valley, it is possible to direct the harvest of irrigated vines to any season of the year. However, differences in the quality of grapes produced in the first and second halves of the year have been observed, which result mostly from different temperatures and relative air humidity conditions (Lima; Guerra, 2018). Therefore, further studies characterizing grape quality in each production season and associated to different components of the production system are required. Farmers who aim to produce quality juice can use this information.

The aim of this study was to characterize the quality and antioxidant activity of 'BRS Magna' grapes in irrigated crops of the Submedium São Francisco River Valley under the influence of training systems and rootstocks, in production cycles of the first halves of two years.

\section{MATERIAL AND METHODS}

\section{Plant material}

The study was conducted during two production cycles of two years, both in the first half of the year, at the Experimental Field of Bebedouro at Embrapa Semiárido (coordinates $09^{\circ} 09^{\prime} \mathrm{S}$ and $40^{\circ} 22^{\prime} \mathrm{W}$ ), located in the municipality of Petrolina, Pernambuco State, Brazil. Grapes were collected in the first half of 2017 (production cycle from January 12 to April 19, 2017) and in the first half of 2018 (production cycle from January 20 to April 27, 2018). The main meteorological data observed during the study period are shown in Table 1 . 
Table 1: Mean monthly meteorological data of the Experimental Field of Bebedouro at Embrapa Semiárido, referring to the two production cycles of 'BRS Magna' grapevines, in the first halves of 2017 and 2018, from pruning to harvest.

\begin{tabular}{|c|c|c|c|c|c|c|c|c|}
\hline \multirow{2}{*}{$\begin{array}{c}\text { Period } \\
\text { (month/year) }\end{array}$} & \multicolumn{3}{|c|}{$\mathrm{T}\left({ }^{\circ} \mathrm{C}\right)$} & $\mathrm{RH}$ & Rad. & Ws & Rainfall & \multirow{2}{*}{$\begin{array}{c}\text { ETO } \\
\left(\mathrm{mm} \cdot \mathrm{dia}^{-1}\right)\end{array}$} \\
\hline & Max & Mean & Min & $(\%)$ & $\left(\mathrm{MJ} \cdot \mathrm{m}^{-2} \cdot \mathrm{dia}^{-1}\right)$ & $\left(\mathrm{m} \cdot \mathrm{s}^{-1}\right)$ & $(\mathrm{mm})$ & \\
\hline & \multicolumn{8}{|c|}{ Production cycle from January to April, 2017} \\
\hline Jan/17 & 36.0 & 29.3 & 23.4 & 45.1 & 18.23 & 2.41 & 10.00 & 6.26 \\
\hline Feb/17 & 35.8 & 29.1 & 23.4 & 54.0 & 19.81 & 1.96 & 24.00 & 5.81 \\
\hline Mar/17 & 34.2 & 28.8 & 22.6 & 57.6 & 19.81 & 1.77 & 6.00 & 5.49 \\
\hline Apr/17 & 34.2 & 27.8 & 22.5 & 62.0 & 17.37 & 2.41 & 3.00 & 5.37 \\
\hline \multirow[t]{2}{*}{ Average } & 35.1 & 28.8 & 22.9 & 54.7 & 18.80 & 2.13 & 10.81 & 5.73 \\
\hline & \multicolumn{8}{|c|}{ Production cycle from January to April, 2018} \\
\hline Jan/18 & 34.9 & 28.3 & 23.2 & 65.0 & 23.71 & 1.89 & 43.00 & 6.03 \\
\hline $\mathrm{Feb} / 18$ & 33.6 & 27.3 & 23.1 & 79.9 & 21.51 & 1.19 & 66.00 & 4.87 \\
\hline Mar/18 & 34.1 & 27.5 & 22.9 & 81.1 & 22.93 & 0.87 & 109.00 & 4.83 \\
\hline Apr/18 & 32.2 & 25.9 & 21.6 & 79.0 & 22.50 & 1.13 & 101.00 & 4.29 \\
\hline Average & 33.7 & 27.3 & 22.7 & 76.25 & 22.66 & 1.27 & 79.75 & 5.00 \\
\hline
\end{tabular}

$\mathrm{T}$ Mean = Mean temperature; $\mathrm{T}$ Max = Maximum temperature; $\mathrm{T}$ Min = Minimum temperature; RH = Relative humidity; Rad . = Global solar radiation; Ws = Win speed at a 2.0 m height; Rainfall = Accumulated rainfall during the month; ET0= Reference evapotranspiration. Source: Agrometeorological Station of Bebedouro, Petrolina, Pernambuco State, Brazil (Embrapa Semiárido, 2018).

This study was conducted in a vineyard implemented in December 2015 with BRS Magna cultivar. 'BRS Magna' grapevines resulted from the crossing of 'BRS Rúbea' X 'IAC 1398-21' ('Traviú') and is characterized by medium vigor, intermediate cycle, wide climatic adaptation and medium-sized bunches (Ritschel et al., 2014). In the experiment, plants were trained to, according the description mentioned by Creasy and Creasy (2018): 1. overhead trellis, which a series of wires is strung between post supports and the vines trained along the top; 2. VSP that result in a fruiting wire relatively close to the ground and shoots trained upwards from it during the growing season, which in this situation formed a vertical downward curtain; and 3. lyre, which has an instrument-like arrangement of the two VSP-like when viewed end-on. Grapevines were grafted onto rootstocks 'IAC 572', resulted from the crossing of '101-14 Mgt' (Vitis riparia $\mathrm{x}$ V rupestris) X V. caribeae, and 'IAC 766', which is resulted from the crossing of Riparia do Traviú $\mathrm{x} V$. caribaea. Spacing was $3.0 \mathrm{~m}$ between rows and 1.0 $\mathrm{m}$ between plants in all training systems. Pruning system maintained five buds per cane and two buds per spur in all plots. Farming practices followed those used for viticulture in the region (Soares; Leão, 2009).
Experimental design was in randomized blocks, with sub-subplots in time, four replicates, and 5 plants per plot. Treatments were arranged considering that plots were represented by training systems, sub-plots corresponded to rootstocks, and sub-subplots corresponded to production cycles. For the analyses, six bunches were sampled from each plot at harvest time. The identification of harvest time was based on sampling berries from 95 days after pruning to determine soluble solids content and titratable acidity. Bunches were harvested during the morning, on April 19, 2017 and April 27, 2018, when grapes reached soluble solids content and titratable acidity commercially suitable. The harvested bunches were taken to the PostHarvest Physiology Laboratory of Embrapa Semiarido for evaluation.

\section{Quality variables analyzed}

Bunch mass was determined by weighing six bunches, and berry mass was determined by weighing 50 berries using a semi-analytic scale (Acculab, model VI 2400, Florida, EUA) with precision of 0,001 g. Berry resistance to compression was determined by applying force using a circular plate, capable of causing deformation of $10 \%$ of fruit volume, using an electronic texturometer 
(Extralab TA.XT.Plus, Stable Micro Systems, Surrey, United Kingdom). Soluble solids content was obtained by direct reading using a digital refractometer, (ATAGO, model PAL-1, Tokyo, Japan) with accuracy of $0.2^{\circ}$ Brix and results expressed in ${ }^{\circ}$ Brix (AOAC, 2010). Titratable acidity was determined using a digital automatic titrator (Metrohm, modelo Titrino plus 848, Herisau, Switzerland), titrating the sample with $\mathrm{NaOH}$ solution, $0.1 \mathrm{~N}$, until neutralization (AOAC, 2010).

Total soluble sugar contents were quantified using the methodology described by Yemn and Willis (1954). Yellow flavonoid and anthocyanin contents in the skin followed the same extraction and quantification procedure, according to the methodology described by Francis (1982). Results were expressed in $100 \mathrm{~g}^{-1}$, as indicated be:

a) Total anthocyanin content $=$ Absorbance $*$ dilution factor $/ 98.2$

b) Yellow flavonoid content $=$ Absorbance $*$ dilution factor $/ 76.6$

Total extractable polyphenol contents were determined in the skin and berry pulp, using a FolinCiocalteau reagent and gallic acid as reference, following the methodology recommended by Larrauri, Rupérez and Saura-Calixto (1997).

\section{Antioxidant activity determination}

Two usual determination methods were selected: ABTS and DPPH. Antioxidant activity determination using the ABTS (2,2'-azino-bis 3-ethylbenzothiazoline6-sulphonic acid) free radical capture method followed the methodology described by Miller et al. (1993), with adaptations by Rufino et al. (2007a). Antioxidant activity determined by the DPPH (2,2-diphenyl-1-picrylhydrazyl) free radical capture method followed the methodology described by Sánchez-Moreno, Larrauri and SauraCalixto (1998), with adaptations by Rufino et al. (2007b). Determination was performed with both methods using the same extract obtained for total extractable polyphenol quantification.

\section{Statistical analyses}

Data were evaluated for normal distribution and, once this criterion was met, they were submitted to an analysis of variance using the F-test ( $5 \%$ of probability). To analyze the effects of each plot and subplot individually as well as of all possible interactions, mean values were compared using Tukey's test $5 \%$ of probability). The effects of sub-subplots individually were analyzed using F test (Anova) which was conclusive in that situation. It was used the statistical program SISVAR version 5.6.

\section{RESULTS AND DISCUSSION}

\section{Fruit quality}

Bunch mass, berry mass, and titratable acidity had significant differences according to the training system used (Table 2). Lyre favored increased bunch mass compared to overhead trellis. However, it did not differ from VSP. Berry mass was also higher in plants trained to lyre and VSP, compared to overhead trellis, although the difference was only $0.16 \mathrm{~g}$. Research indicates that plants trained to lyre tend to be more productive, possibly due to the divided vegetative canopy (Reynolds; Heuvel, 2009). On the other hand, it is expected that plants trained to VSP have low yield, in order to improve berry quality. Ferrer, Echeverría and Gonzalez-Neves (2015) reported a higher production due to higher number of berries and heavier berries in 'Merlot' grapevines trained to lyre when compared to VSP. Similar results of bunch and berry mass in both training systems might result from common physiological adaptations of bunches, or even of other parts of the plant, in both treatments.

Bunch mass depends on several factors, some of which were not evaluated in the present study, such as mineral uptake, Ravaz index, berry load per plant, leaf area, among others (Santos; Pereira; Moreira, 2015). Particularly factors that are not related to crop management, which was the same in all plants in this

Table 2: Bunch mass, berry mass and titratable acidity in 'BRS Magna' grapes under the influence of training systems.

\begin{tabular}{ccccc}
\hline Variable & Vertical shoot positioning & Overhead trellis & Lyre & CV (\%) \\
\hline Bunch mass $(\mathrm{g})$ & $123.44 \mathrm{ab}$ & $121.73 \mathrm{~b}$ & $132.31 \mathrm{a}$ & 7.05 \\
Berry mass $(\mathrm{g})$ & $2.59 \mathrm{a}$ & $2.43 \mathrm{~b}$ & $2.57 \mathrm{ab}$ & 7.16 \\
Titratable acidity (g tartaric acid $100 \mathrm{~mL}^{-1}$ ) & $0.61 \mathrm{~b}$ & $0.52 \mathrm{c}$ & $0.66 \mathrm{a}$ & 8.30 \\
\hline
\end{tabular}

*Means followed by the same lowercase letter in the row do not differ from each other using Tukey's Test ( $p \leq 0.05)$. 
study, might have played a role in the lack of difference between bunch and berry mass in grapevines trained to VSP and lyre. Another factor that might explain the higher bunch mass of grapes trained to VSP and lyre is the expected lower number of bunches per plant compared to overhead trellis system. As a consequence, higher number of bunches plants trained to overhead trellis caused them to be smaller than those in grapevines trained to lyre and VSP (Creasy; Creasy, 2018).

Berry resistance to compression was significantly affected by rootstock (Table 3 ). Grape berries of plants grafted onto 'IAC 572' were characterized by lower resistance to compression. Texture elements, such as resistance to compression, depend on factors such as genetic traits; tissue morphology and turgidity; phenological stages and substages; plant management, particularly of water and nutrients, among others (Maury et al., 2009). Lower values were recorded in a study conducted by Ribeiro, Lima and Alves (2012) with 'BRS Cora' grapes grafted onto rootstock 'IAC 572', which ranged from 2.17 to $5.11 \mathrm{~N}$. The higher values observed in 'BRS Magna' grapes might be due to genetic traits. In addition, plant management and berry water content at harvest are related to changes on texture including berry resistance do compression (Ribeiro; Lima; Alves, 2012). The latter stands out as water losses to the atmosphere or to the plant cause the berry to be more elastic, and consequently, more resistant to deformation (Crupi et al., 2016).

Table 3: Berry resistance to compression and yellow flavonoids content in 'BRS Magna' grape skins under the influence of rootstocks.

\begin{tabular}{crrc}
\hline Variable & IAC 572 & IAC 766 & CV (\%) \\
\hline $\begin{array}{c}\text { Berry resistance to } \\
\text { compression (N) }\end{array}$ & $6.92 \mathrm{~b}$ & $7.43 \mathrm{a}$ & 8.56 \\
$\begin{array}{c}\text { Yellow flavonoids } \\
\left.\text { content (mg 100 } \mathrm{g}^{-1}\right)\end{array}$ & $113.30 \mathrm{a}$ & $104.20 \mathrm{~b}$ & 7.52 \\
\hline
\end{tabular}

*Means followed by the same lowercase letter in the row do not differ from each other using F Test ( $p \leq 0.05)$.

Lower berry resistance is an indication of pulp tissue softening, with consequent easier pedicel-berry detachment. During juice processing, in the berry crushing stage, where solid parts (seed and skin) are separated from the juice, it is important that berry resistance to compression is known in order to estimate the yield in destemming and pressing operations.
Plants trained to overhead trellis produced grapes with higher titratable acidity: $0.52 \mathrm{~g}$ of tartaric acid 100 $\mathrm{mL}^{-1}$ (Table 2). Results of studies conducted with other cultivars, as reported by Ferrer, Echeverría and GonzalezNeves (2015) indicated that 'Merlot' grapes trained to lyre had lower titratable acidity compared to overhead trellis. These authors evaluated the temperatures inside the canopy and observed that plants trained to lyre were expected to have higher foliar temperature than those trained to overhead trellis, as there is higher exposure to sunlight. However, this response was only recorded in the early ripening stage, reverting rapidly due to leaf exposure and to the higher number of bunches located inside the canopy, which possibly increased ventilation flow, causing lower vapor pressure and reduced temperature. Therefore, the mentioned authors reinforced that a lower air circulation could explain the higher temperatures in plants trained to overhead trellis. Higher temperatures, in turn, could explain the higher degradation of organic acids of 'BRS Magna' cultivar trained to this system.

Titratable acidity was also affected by the significant interaction between production cycles and rootstocks (Table 4). The lowest values were observed when rootstock 'IAC 572' was adopted in the cycle referring to the first half of 2017. Differences between cycles might be attributed to climatic conditions in the period. During the first half of 2018 and as shown in Table 1, lower temperatures than those observed in the previous cycle during ripening might have reduced the degradation rate of organic acids. It is stablished the influence of temperature on respiratory rates, which determine the cellular consumption of organic acids (Lima; Guerra, 2018).

Silva et al. (2018), evaluating 'Isabel Precoce', 'BRS Cora', and 'BRS Carmem' grapes grafted onto rootstocks 'IAC 766' and 'IAC 572' under tropical humid climate in the southeastern region of Brazil, indicated the influence of rootstocks on soluble solid contents and titratable acidity. Considering these variables, there were differences between rootstocks in the three production cycles studied. In these cultivars, rootstock 'IAC 766' determined higher soluble solid contents and lower titratable acidity. Different results when using the same rootstocks for 'BRS Magna' grapes might be explained by the differential interaction between scion cultivars and rootstocks, affecting several responses, including the degradation of organic acids. The specificity of this interaction and environmental influence prompts new scientific research to be conducted on each cultivar, under regional conditions. 
Table 4: Titratable acidity, soluble solids content, total extractable polyphenols of the skin and the pulp and antioxidant activity by ABTS free radical capture method in 'BRS Magna' grapes under the influence of production cycles and rootstocks.

\begin{tabular}{|c|c|c|c|}
\hline \multirow{2}{*}{ Production cycle } & \multicolumn{2}{|c|}{ Rootstock } & \multirow{2}{*}{$\begin{array}{l}C V \\
(\%)\end{array}$} \\
\hline & IAC 572 & IAC 766 & \\
\hline & \multicolumn{3}{|c|}{ Titratable acidity (g tartaric acid $100 \mathrm{~mL}^{-1}$ ) } \\
\hline First semester of 2017 & $0.55 \mathrm{bB}$ & $0.62 \mathrm{aA}$ & \multirow{2}{*}{8.30} \\
\hline First semester of 2018 & $0.62 \mathrm{aA}$ & $0.60 \mathrm{aA}$ & \\
\hline & \multicolumn{3}{|c|}{ Soluble solids ( ${ }^{\circ}$ Brix) } \\
\hline First semester of 2017 & $23.0 \mathrm{aA}$ & $23.3 a A$ & \multirow{2}{*}{4.41} \\
\hline \multirow[t]{2}{*}{ First semester of 2018} & $19.5 \mathrm{bA}$ & $18.5 \mathrm{bB}$ & \\
\hline & \multicolumn{3}{|c|}{ Polyphenols (mg galic acid $100 \mathrm{~g}^{-1}$ ) } \\
\hline First semester of 2017 & $285.19 \mathrm{bA}$ & $304.85 b A$ & \multirow{2}{*}{7.48} \\
\hline \multirow[t]{2}{*}{ First semester of 2018} & 399.18aA & $344.09 a B$ & \\
\hline & & $\left.\mathrm{xg}^{-1}\right)$ & \\
\hline First semester of 2017 & $19.40 \mathrm{bA}$ & $20.41 \mathrm{bA}$ & \multirow{2}{*}{5.26} \\
\hline First semester of 2018 & $31.22 \mathrm{aA}$ & $28.16 a B$ & \\
\hline
\end{tabular}

ABTS - (2,2'-azino-bis 3-ethylbenzothiazoline-6-sulphonic acid)

*Means followed by the same lowercase letter in the column or uppercase letter in the row do not differ from each other in relation to production cycles and rootstocks, respectively, using Tukey's test ( $p \leq 0.05)$.

Soluble solids content was affected by the interaction between production cycles and rootstocks (Table 4), as well as between production cycles and training systems (Table 5). The highest soluble solids contents were observed in grapes produced in the first half of 2017, with values around $23.0^{\circ}$ Brix (Tables 4 and 5). In the first half of 2018, rootstocks differed from each other, and plants grafted onto 'IAC 572' had higher content. Ritschel et al. (2014) observed that 'BRS Magna' grape has had good performance with rootstock 'IAC 572' in the Brazilian states where it has been evaluated. Therefore, differences might be associated to the interaction between 'BRS Magna' cultivar and rootstock 'IAC 572', promoting higher degradation of organic acids and higher translocation of soluble solids. 'IAC 572' and 'IAC 766' are considered vigorous rootstocks. Gutiérrez-Gamboa et al. (2018) emphasizes that vigorous rootstocks give rise to a long vegetative cycle to the graft, delaying ripening. Results of this study suggest a faster ripening related to higher degradation of organic acids and higher accumulation of soluble solids in berries harvested from plants grafted on 'IAC 572'. Therefore, it can be considered relatively more vigorous than 'IAC 766' in the experimental or regional conditions of this study.
Despite the significant interaction between production cycles and training systems, differences in soluble solids contents were associated predominantly with cycles (Tables 4 and 5). In the first half of 2017, the highest accumulation of soluble solids might have been stimulated mostly by the maximum temperatures (average of $35.1^{\circ} \mathrm{C}$ ), which were higher during berry ripening, along with high radiation of $18.8 \mathrm{MJ} \mathrm{m}^{-2} \mathrm{dia}^{-1}$ (Table 1), a condition that might provide higher photosynthetic efficiency, causing accumulation of carbohydrates, which are an important constituent of soluble solids. Environmental conditions, mainly global radiation and temperature, might determine either the synthesis or degradation of compounds that affect berry quality. Therefore, the lower average values of temperatures and global radiation might have reduced the metabolism in berries harvest in the first half of 2018 . Leão et al. (2018), studying the same region and with the same cultivar trained to overhead trellis and grafted onto 'IAC 572', reported soluble solid contents of $17.5^{\circ}$ Brix, and observed no influence of production cycle.

The highest total soluble solid contents were observed in the first half of 2017 in all combinations between training systems and rootstocks (Table 6), which corroborates our findings regarding soluble solid contents (Tables 4 and 5). 
Table 5: Soluble solids content, yellow flavonoids in the skin and antioxidant activity by ABTS and DPPH free radicals capture methods in 'BRS Magna' grapes under the influence of production cycles and training systems.

\begin{tabular}{|c|c|c|c|c|}
\hline \multirow{2}{*}{ Production cycle } & \multicolumn{3}{|c|}{ Training system } & \multirow{2}{*}{ CV $(\%)$} \\
\hline & Vertical shoot positioning & Overhead trellis & Lyre & \\
\hline & \multicolumn{3}{|c|}{ Soluble solids ('Brix) } & \\
\hline First semester of 2017 & $22.7 \mathrm{aA}$ & $23.8 \mathrm{aA}$ & $23.0 \mathrm{aA}$ & \multirow{2}{*}{4.41} \\
\hline \multirow[t]{2}{*}{ First semester of 2018} & $18.8 \mathrm{bA}$ & $18.6 \mathrm{bA}$ & $19.4 \mathrm{bA}$ & \\
\hline & Yellow & oids (mg $100 \mathrm{~g}^{-1}$ ) & & \\
\hline First semester of 2017 & $132.78 \mathrm{aA}$ & $136.16 \mathrm{aA}$ & $130.80 a A$ & \multirow{2}{*}{7.52} \\
\hline \multirow[t]{2}{*}{ First semester of 2018} & $89.02 \mathrm{bA}$ & $76.95 \mathrm{bB}$ & $86.81 \mathrm{bAB}$ & \\
\hline & & ( Trolox g-1) & & \\
\hline First semester of 2017 & $17.10 \mathrm{bB}$ & $27.75 b A$ & $14.87 \mathrm{bC}$ & \multirow{2}{*}{5.26} \\
\hline \multirow[t]{2}{*}{ First semester of 2018} & $24.42 \mathrm{aC}$ & $33.21 \mathrm{aA}$ & $31.44 \mathrm{aB}$ & \\
\hline & DPF & uit $g \mathrm{DPPH}^{-1}$ ) & & \\
\hline First semester of 2017 & $2636.38 \mathrm{bB}$ & $1204.62 \mathrm{aA}$ & $2628.73 a \mathrm{~B}$ & \multirow{2}{*}{6.72} \\
\hline First semester of 2018 & $2348.95 \mathrm{aA}$ & $2146.29 \mathrm{bA}$ & $3528.63 b B$ & \\
\hline
\end{tabular}

ABTS (2,2'-azino-bis 3-ethylbenzothiazoline-6-sulphonic acid), DPPH (2,2-diphenyl-1-picrylhydrazyl)

*Means followed by the same lowercase letter in the column or uppercase letter in the row do not differ from each other in relation to production cycles and training system, respectively, using Tukey's test $(p \leq 0.05)$.

Table 6: Total soluble solids and total anthocyanin contents in 'BRS Magna' grape under the influence of production cycles, training systems, and rootstocks.

\begin{tabular}{|c|c|c|c|c|c|}
\hline \multirow{2}{*}{ Training system } & \multicolumn{2}{|c|}{ First semester of 2017} & \multicolumn{2}{|c|}{ First semester of 2018} & \multirow{2}{*}{$\begin{array}{l}\mathrm{CV} \\
(\%)\end{array}$} \\
\hline & IAC 572 & IAC 766 & IAC 572 & IAC 766 & \\
\hline & \multicolumn{4}{|c|}{ Total soluble sugars (g $100 \mathrm{~g}^{-1}$ ) } & \\
\hline Vertical shoot positioning & $20.8 a \mathrm{Aa}$ & $21.6 a \mathrm{Aa}$ & $15.2 a \mathrm{Ab}$ & $16.1 a b \mathrm{Ab}$ & \\
\hline Overhead trellis & $22.1 a \mathrm{Aa}$ & $22.2 a \mathrm{Aa}$ & $15.3 a \mathrm{Bb}$ & $16.7 a \mathrm{Ab}$ & 4.38 \\
\hline \multirow[t]{2}{*}{ Lyre } & $20.9 a \mathrm{Aa}$ & $21.9 a \mathrm{Aa}$ & $16.0 a \mathrm{Ab}$ & $14.7 b \mathrm{Bb}$ & \\
\hline & \multicolumn{4}{|c|}{ Total anthocyanins (mg $100 \mathrm{~g}^{-1}$ ) } & \\
\hline Vertical shoot positioning & $1492.46 a \mathrm{Ab}$ & $1578.82 a \mathrm{Ab}$ & $2842.41 a \mathrm{Aa}$ & 2956.91aAa & \\
\hline Overhead trellis & $1257.24 a b A \mathbf{b}$ & $1070.55 b A \mathbf{b}$ & $2734.72 a \mathrm{Ba}$ & 2935.04aAa & 6.68 \\
\hline Lyre & $1222.26 b A \mathbf{b}$ & $1092.08 b A \mathbf{b}$ & $2946.47 a \mathrm{Aa}$ & $2495.10 b \mathrm{Ba}$ & \\
\hline
\end{tabular}

*Means followed by the same lowercase letter in italics in the column, comparing training systems associated to each rootstock and their interaction with production cycle, and means followed by the same uppercase letter, comparing rootstocks associated to each training system and their interaction with production cycle, do not differ from each other using Tukey's Test ( $p \leq 0.05$ ). On the rows, mean values followed by the same lowercase letter in bold, comparing production cycles associated to each training system and their interaction with rootstocks, do not differ from each other using Tukey's Test $(p \leq 0.05)$.

In the first half of 2018 , total soluble solid content in grapes did not differ between treatments with the three training systems, as long as the rootstock adopted was 'IAC 572' (Table 6). Regarding rootstock association with each training system, overhead trellis with 'IAC 572 ' and lyre with 'IAC 766' resulted in the lowest contents. Training systems affect sunlight penetration through bunches. Thus, bunches of plants trained to VSP are more exposed to sunlight in one period of the day. Bunches trained to lyre are the most exposed to solar radiation while overhead trellis allows for higher berry shading than the others. This differential exposure of 
leaves to sunlight causes a variation in photosynthetic efficiency, leading to accumulation of carbohydrates in berries. Results indicate that it is necessary to consider the combination of these components together, when the focus is to favor accumulation of soluble sugars in berries (Bem et al., 2015; Creasy; Creasy, 2018; De la Fuente et al., 2007; Ferrer; Echeverría; Gonzalez-Neves, 2015; Soares; Leão, 2009). Ferrer, Echeverría and GonzalezNeves (2015) also reported that accumulation of sugars in berries depends on the training system, which interferes with their exposure to solar radiation and determines the microclimate under the canopy.

Yellow flavonoid synthesis in the skin was stimulated in plants grafted onto 'IAC 572', and a 9\% increase in content was observed (Table 3 ). There is little research in literature considering the effects of rootstocks on the phenolic quality of grapes for juice making. Differences between rootstocks and canopies indicate that 'IAC 572' boosted the accumulation of yellow flavonoids in 'BRS Magna' grape skin. According to Nassur et al. (2017), changes in plant physiology derived from the use of different rootstocks might interfere in secondary metabolite composition, resulting in specific phenolic composition of berries.

The climatic conditions of the first half of 2017 led to a higher synthesis of yellow flavonoids in the skin, reaching contents of 130.80 to $136.16 \mathrm{mg} 100 \mathrm{~g}^{-1}$ in the training systems (Table 5). During the first half of 2018, contents were lower but plants trained to VSP stood out, as they produced grapes with higher yellow flavonoid contents in the skin compared to those trained to overhead trellis. These varying responses between productive cycles in the same period of the year might result from climatic variations. Therefore, during the first half of 2017, temperatures were high and associated to high global solar radiation during grape ripening, which might have stimulated a higher accumulation of yellow flavonoids. In general, flavonoids biosynthesis results from the exposure of fruits to stressful conditions as reported by Kro'l, Amarowicz and Weider (2014) referring to drought. Similarly, stresses promoted by exposure to radiation and high temperatures might induce that biosynthesis. Pastore et al. (2017) highlighted increases on flavonoids biosynthesis in berries under influence of high temperatures and exposure to sunlight. As the effect of temperatures is determining for flavonoid synthesis, high values in the first half of 2017 support the higher yellow flavonoid contents in 'BRS Magna' grapes (Table 5).

In a study conducted by Farhadi et al. (2016), who studied berry skins of different grape cultivars in Iran, yellow flavonoid contents varied from 9.19 to

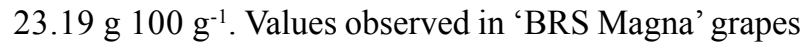
are quite higher, suggesting this is a genetic trait, but which can be optimized by environmental conditions and by the interaction with rootstocks and training systems. This group of factors directly affects berry composition, which in turn affects the accumulation of compounds. Concerning phenolics, part of them might be of bioactive nature, bringing benefits to consumers of grape juice elaborated from 'BRS Magna' grapes.

Anthocyanin contents were affected by the interaction between training systems, rootstocks, and production cycles (Table 6). Plants trained to VSP on both rootstocks and to overhead trellis on 'IAC 766' had higher synthesis in the first half of 2018. The total anthocyanin contents observed in this study, under semiarid conditions, characterize its high accumulation, thus reflecting the genetic potential of the cultivar and the stimulus of incident solar radiation throughout the study. Anthocyanin contents remained high in both cycles evaluated (Table 6 ). However, during the first half of 2018, values were 1.6 to 2.8 higher. This response might be related to differences in climatic conditions between cycles, although both occurred in the same period of each year. It is worth of note that maximum temperatures were higher and global solar radiation was lower in the first half of 2017, which possibly affected the final contents. According to Hunter and Bonnardot (2011), climatic conditions change the contents of these compounds. In general, daytime temperatures between $25-30^{\circ} \mathrm{C}$ and nocturnal temperatures between $16-25^{\circ} \mathrm{C}$ are responsible for anthocyanin synthesis and stability. Since temperatures are generally out of the ideal range in tropical regions, management can to alleviate the damages effects for pigments and other chemical constituents. The ideal training system associated to season of mild temperatures might represent a proper technical strategy to get better results. Some effort in that direction for the Submedium São Francisco Valley can be considered when maximum and minimum temperatures in a certain season were lower and solar radiation was high, allowing higher anthocyanin contents.

Farhadi et al. (2016) studied anthocyanin contents in berry skin of Vitis vinifera L. cultivars grown in a cold semiarid climate, in Iran, and reported values of 670.0 mg $100 \mathrm{~g}^{-1}$, which were considered quite high. In 'BRS Magna' skins, contents were 1.6 to 4.4 times as high, which emphasizes the potential of compounds present in this cultivar. Another factor that might explain high anthocyanin contents generally observed in plants trained to overhead trellis and VSP with descending curtain combined with the rootstocks of the present study, was 
bunch shading. Shading provides protection from direct solar radiation and from high temperatures, which in excess degrade anthocyanins. According to De la Fuente et al. (2007), suitable shading provided by some training systems increases color intensity, total anthocyanin synthesis, and polyphenol contents in grapes.

Comparing production cycles associated with rootstocks, a higher accumulation of total extractable polyphenols was observed in grapes harvested from plants grafted onto 'IAC 572' in the first half of 2018 (Table 4). This response is possibly related to anthocyanin synthesis, which represents a considerable part of extractable polyphenols from red grapes, and to the climatic conditions in the first half of 2018, with suitable temperature and solar radiation for polyphenol accumulation and stability. A study conducted by Bergqvist, Dokoozlian and Ebisuda (2001) emphasized that grape berry composition is affected by the amount and quality of light and by the effects of exposure to sunlight. The authors pointed out that the exposure of bunches to solar radiation increases the synthesis of some quality compounds. However, when berry temperature reaches values higher than $30{ }^{\circ} \mathrm{C}$, there is reduced anthocyanin content, phenolic compounds, and antioxidant activity. As maximum temperature in the first half of 2018 $\left(33.7^{\circ} \mathrm{C}\right)$ were lower than in $2017\left(35.1{ }^{\circ} \mathrm{C}\right)$, probably they were a decisive factor to induce high polyphenols biosynthesis. Additionally, canopy management practices in vineyards are factors to be considered, mostly in regions with high temperature, where prolonged exposure of bunches to solar radiation must be avoided.
The interaction between rootstock and training system indicated that, the use of 'IAC 572' with VSP and lyre favored the accumulation of total extractable polyphenols (Table 7). Grapevines trained to overhead trellis and grafted onto both rootstocks yielded grapes with the highest contents, ranging from 406.87 to $429.76 \mathrm{mg}$ of gallic acid $100 \mathrm{~g}^{-1}$. These results suggest that total extractable polyphenol contents were maximized with this combination. According to Vršič, Pulko and Kocsis (2015), the relationship of canopy with rootstock is extremely specific and depends on the affinity and compatibility of soil combinations and on climatic adaptation. In general, rootstocks might modify leaves, and consequently, photosynthesis, which might affect the pathways of primary and secondary grapevine metabolites, hence changing the chemical quality of grapes (Lee; Steenwerth, 2013). In this study, the use of 'IAC 572' might have maximized extractable polyphenol contents, and consequently, antioxidant activity, through the physiological changes that it might have caused in the scion cultivar.

Studies conducted by Burin et al. (2014), with some 'labrusca' grape cultivars for juice, such as 'Isabel', 'Concord', and 'Bordô', reported that polyphenol contents ranged from 56.6 to $106.2 \mathrm{mg} 100 \mathrm{~g}^{-1}$. The authors deemed these values high, and considered these cultivars as remarkable sources of phenolic compounds. The results observed in the present study with 'BRS Magna' grapes might be up to four times as high, which confirms the high bioactive potential of this cultivar in the environmental conditions of the study region.

Table 7: Total extractable polyphenols in the skin and pulp and antioxidant activity by ABTS and DPPH free radicals capture methods in 'BRS Magna' grapes under the influence of rootstock and training system.

\begin{tabular}{|c|c|c|c|c|}
\hline \multirow{2}{*}{ Rootstock } & \multicolumn{3}{|c|}{ Training system } & \multirow{2}{*}{$\begin{array}{l}\text { CV } \\
(\%)\end{array}$} \\
\hline & Vertical shoot positioning & Overhead trellis & Lyre & \\
\hline \multicolumn{5}{|c|}{ Polyphenols (mg galic acid·100 $\mathrm{g}^{-1}$ ) } \\
\hline IAC 572 & $290.93 a C$ & $429.76 \mathrm{aA}$ & $328.75 a B$ & \multirow{2}{*}{7.48} \\
\hline IAC 766 & $261.30 \mathrm{bB}$ & $406.87 \mathrm{aA}$ & $228.35 \mathrm{bB}$ & \\
\hline \multicolumn{5}{|c|}{ ABTS $\left(\mu \mathrm{M}\right.$ Trolox $\left.\cdot g^{-1}\right)$} \\
\hline IAC 572 & $22.68 \mathrm{aB}$ & $30.74 \mathrm{aA}$ & $22.51 \mathrm{aB}$ & \multirow{2}{*}{5.26} \\
\hline IAC 766 & $18.84 \mathrm{bC}$ & $30.23 \mathrm{aA}$ & $23.80 \mathrm{aB}$ & \\
\hline \multicolumn{5}{|c|}{$\mathrm{DPPH}\left(\mathrm{g}\right.$ fruit g DPPH ${ }^{-1}$ ) } \\
\hline IAC 572 & $2413.82 \mathrm{aB}$ & 1602.23aA & $3244.71 b c$ & \multirow{2}{*}{6.72} \\
\hline IAC 766 & $2571.51 \mathrm{aB}$ & 1748.71aA & $2912.66 a C$ & \\
\hline
\end{tabular}

ABTS (2,2'-azino-bis 3-ethylbenzothiazoline-6-sulphonic acid), DPPH (2,2-diphenyl-1-picrylhydrazyl)

*Means followed by the same lowercase letter in the column or uppercase letter in the row do not differ from each other in relation to rootstock and training system, respectively, using Tukey's test ( $p \leq 0.05)$. 


\section{Antioxidant activity}

Antioxidant activity, determined using the ABTS ${ }^{\bullet}$ free radical capture method, was affected by interactions between rootstocks and production cycles (Table 4), training systems and production cycles (Table 5), and training systems and rootstocks (Table 7). Using this method, the antioxidant activity was higher in grapes grown in the first half of 2018, mostly those grafted onto rootstock 'IAC 572' (Table 4). Silva et al. (2019) defended the thought that the scion-rootstock interaction can have a greater influence on grape juice antioxidant capacity than the isolated effect on the rootstock. Therefore, it is reasonable to consider that this response in grape juice is due to the characteristics presented by the berries.

For both production cycles, overhead trellis maximized antioxidant activity, determined using this method, as indicated by the highest values, which corresponded to 27.75 and $33.21 \mu \mathrm{M}$ Trolox $\mathrm{g}^{-1}$, in the first half of 2017 and 2018, respectively (Table 5). The significant interaction between training systems and rootstocks indicated that plants grafted onto 'IAC 572' have higher antioxidant activity using the ABTS free radical capture method (Table 7). Regarding the use of 'IAC 766', the best responses were associated to overhead trellis and lyre, in that order. Considering that rootstock performance is not always uniform, rootstocks should be tested with each cultivar and at each site (Silva et al., 2018).

When antioxidant activity is determined by the DPPH free radical capture method, which was adopted in the present study, the lowest value represents the highest antioxidant activity of the sample, as results are interpreted as the amount of fruit that needs to be consumed to obtain an activity equivalent to the reference radical. There was a significant effect of the interaction between training systems and production cycles (Table 5) and between training systems and rootstocks (Table 7) on this variable. In the production cycle of the first half of 2017, the use of overhead trellis resulted in grapes with higher antioxidant activity, determined by the DPPH free radical capture method, while the best response in the first half of 2018 was observed in grapes harvested from plants trained to VSP (Table 5). The use of this method to determine antioxidant activity indicated that, in general, rootstock 'IAC 572' associated with overhead trellis allowed for a higher antioxidant potential in grapes, similar to what was observed using the ABTS method (Table 7). Conversely, lyre resulted in grapes with lower antioxidant activity. This response was mitigated when this training system was combined with rootstock 'IAC 766', even though it did not show the same potential as 'IAC 572'.

Antioxidant activity values observed in berries of 'BRS Magna' cultivar were higher than those observed by Lingua et al. (2016) in red grapes ('Syrah', 'Merlot', and 'Cabernet Sauvignon'), with values ranging from 14.5 to $23.6 \mu \mathrm{M}$ Trolox $\mathrm{g}^{-1}$ using the ABTS method. The values of the same cultivars varied from 10.2 to $22.2 \mu \mathrm{M}$ Trolox $\mathrm{g}^{-1}$, in the same order mentioned, when DPPH was adopted as radical and Trolox solution was adopted as control to determine antioxidant activity. These cultivars are recognized by their highly antioxidant activity. Since the values observed with the use of ABTS are similar to that found for 'BRS Magna', the functional potential of this cultivar is corroborated.

Considering that grapevines trained to overhead trellis in the present study were characterized by a higher antioxidant activity, determined using both the ABTS and DPPH free radical capture methods, it can be inferred that the shading typical of this training system is important to prevent the degradation of antioxidant compounds in a tropical semiarid climate. Moreover, variations in responses resulting from the significant interaction between the studied factors prompt further scientific research focused on the combination between scion cultivar, rootstock, and training system over successive production cycles, might be deeply studied. Complementary information might include microclimate and architecture of canopy, leaf surface, bunches density and others aiming a maximum quality of the grapes associated to satisfactory yields.

\section{CONCLUSIONS}

The meteorological conditions of each production cycle affected titratable acidity, soluble solids, total soluble sugars and yellow flavonoids of the berries. Under mild temperatures and higher global radiation, they also led to a higher anthocyanin accumulation, total extractable polyphenols, and antioxidant activity using the ABTS and DPPH methods, but the training system and rootstock adopted affect the intensity of responses. VSP favored high yellow flavonoid contents, total soluble sugars, anthocyanins, and, when associated to lower temperatures and higher global radiation, result in higher antioxidant activity, determined using the DPPH free radical method. With VSP, 'BRS Magna' grapes grafted onto rootstock 'IAC 572' had differentiated antioxidant activity and total extractable polyphenol content, characterizing a high functional potential. 


\section{REFERENCES}

ASSOCIATION OF OFFICIAL AGRICULTURAL CHEMISTS - AOAC. Official methods of analysis of the Association of the Agricultural Chemists. 18. ed. Gaithersburg: AOAC, 2010. 1025p.

BEM, B. P. et al. Effect of Y-trellis and vertical shoot positioning training systems on downy mildew and botrytis bunch rot of grape in highlands of southern Brazil. Scientia Horticulturae, 185(30):162-166, 2015.

BERGQVIST, J.; DOKOOZLIAN, N.; EBISUDA, N. Sunlight exposure and temperature effects on berry growth and composition of Cabernet Sauvignon and Grenache in the Central San Joaquin Valley of California. American Journal of Enology and Viticulture, 52(1):1-7, 2001.

BURIN, V. M. et al. Bioactive compounds and antioxidant activity of Vitis vinifera and Vitis labrusca grapes: Evaluation of different extraction methods. Microchemical Journal, 114(1):155-163, 2014.

CREASY, G. L.; CREASY, L. L. Grapes. $2^{\circ}$ ed. Oxfordshire: CAB. (Crop Production Science in Horticulture Series, 16). 416p. 2018.

CRUCELLO, J. et al. Characterization of the aroma profile of novel Brazilian wines by solid-phase microextraction using polymeric ionic liquid sorbent coatings. Analytical and Bioanalytical Chemistry, 410(19):4749-4762, 2018.

CRUPI, P. et al. Girdling and gibberellic acid effects on yield and quality of a seedless red table grape for saving irrigation water supply. European Journal of Agronomy, 80(1):21-31, 2016.

DE LA FUENTE, M. et al. Efecto del sistema de conducción en climas semiáridos sobre la maduración, composición de la baya y la exposición de los racimos en Vitis vinifera L. cv. Syrah. Revista Enología, 4:1-9, 2007.

DIAS, F. A. et al. Rootstock on vine performance and wine quality of 'Syrah' under double pruning management. Scientia Agricola, 74(2):134-141, 2017.

EMBRAPA SEMIÁRIDO. Dados meteorológicos. 2018. Available in: <http://www.cpatsa.embrapa.br:8080/servicos/ dadosmet/estacoes/index.html>. Access in: May, 10, 2018.

FAO-OIV. Table and dried grapes: World data available. FAOOIV Focus 2016. Available in: <http://www.oiv.int/js/lib/ pdfjs/web/viewer.html?file=/public/medias/5268/fao oivfocus-2016.pdf.> Access in: August 09, 2018.
FARHADI, K. et al. Determination of phenolic compounds content and antioxidant activity in skin, pulp, seed, cane and leaf of five native grape cultivars in West Azerbaijan province, Iran. Food Chemistry, 199(15):847-855, 2016.

FERRER, M.; ECHEVERRÍA, G.; GONZALEZ-NEVES, G. Influence of the microclimate defined by the training system on the vineyard behaviour and the oenological quality of Merlot grapes. International Journal of Agricultural Sciences and Natural Resources, 2(4):95-108, 2015.

FRANCIS, F. J. Analysis of anthocyanins. In: MARKAKIS, P. Anthocyanins as food colors. New York: Academic Press, 1982. v.1, p.181-207.

GUTIÉRREZ-GAMBOA, G. et al. Rootstock effects on grape anthocyanins, skin and seed proanthocyanidins and wine color and phenolic compounds from Vitis vinifera $\mathrm{L}$. Merlot grapevines. Journal of Science of Food and Agriculture, 99:2846-2854. 2018.

HUNTER, J.; BONNARDOT, V. Suitability of some climatic parameters for grapevine cultivation in South Africa, with focus on key physiological processes. South African Journal of Enology and Viticulture, 32(1):137-154, 2011.

KRO'L, A.; AMAROWICZ, R.; WEIDNER, S. Changes in the composition of phenolic compounds and antioxidant properties of grapevine roots and leaves (Vitis vinifera L.) under continuous of long-term drought stress. Acta Physiologiae Plantarum, 36(6):1491-1499, 2014.

LARRAURI, J. A.; RUPÉREZ, P.; SAURA-CALIXTO, F. Effect of drying temperature on the stability of polyphenols and antioxidant activity of red grape pomace peels. Journal of Agricultural and Food Chemistry, 45(4):1390-1393, 1997.

LEÃO, P. C. S. et al. Yield and physicochemical characteristics of 'BRS Magna' and 'Isabel Precoce' grapes influenced by pruning in the São Francisco River Valley. Ciência Rural, 48(6):1-6, 2018.

LEE, J.; STEENWERTH, K. L. 'Cabernet Sauvignon' grape anthocyanin increased by soil conservation practices. Science Horticulturae, 159(30):128-133, 2013.

LIMA, M. S. dos et al. Phenolic compounds, organic acids and antioxidant activity of grape juice produced from new Brazilian varieties planted in the Northeast Region of Brazil. Food Chemistry, 161(15):94-103, 2014.

LIMA, M. A. C. de; GUERRA, C. C. Colheita e pós-colheita. In: MOTOIKE, S.; BORÉM, A. (Org.). Uva: do plantio à colheita. 1ed.Viçosa: UFV, 2018, v.1, p.163-185. 
LINGUA, M. S. et al. From grape to wine: changes in phenolic composition and its influence on antioxidant activity. Food Chemistry, 208(1):228-238, 2016.

MARGRAF, T. et al. Effects of geographical origin, variety and farming system on the chemical markers and in vitro antioxidant capacity of Brazilian purple grape juices. Food Research International, 82(2016):145-155, 2016.

MARIANI, J. A.; NAVA, G. A. Productivity and chemical quality of grapevines cultivated in agroecological system under subtropical climate. Revista Brasileira de Fruticultura, 40(5):e-924, 2018.

MAURY, C. et al. Development of a mechanical texture test to evaluate the ripening process of Cabernet Franc grapes. Journal of Texture Studies, 40(5):511-535, 2009.

MILLER, N. J. et al. A novel method for measuring antioxidant capacity and its application to monitoring the antioxidant status in premature neonates. Clinical Science, 84(4):407412, 1993.

NASSUR, R. C. M. R. et al. Rootstock influencing the quality and biogenic amines content on Syrah tropical wines. Comunicata Scientiae, 8(2):202-208, 2017.

PASTORE, C. et al. Anthocyanin and flavonol composition response to veraison leaf removal on Cabernet Sauvignon, Nero d'Avola, Raboso Piave and Sangiovese Vitis vinifera L. cultivars. Scientia Horticulturae, 218(1):147-155, 2017.

REYNOLDS, A. G.; HEUVEL, J. E. V. Influence of grapevine training systems on vine growth and fruit composition: A review. American Journal of Enology and Viticulture, 60(3):251-268, 2009.

RIBEIRO, T. P.; LIMA, M. A. C.; ALVES, R. E. Maturação e qualidade de uvas para suco em condições tropicais, nos primeiros ciclos de produção. Pesquisa Agropecuária Brasileira, 47(8):1057-1065, 2012.
RITSCHEL, P. et al. 'BRS Magna' - A novel grape cultivar for juice making, with wide climatic adaptation. Crop Breeding and Applied Biotechnology, 14(4):266-269, 2014.

RUFINO, M. S. M. et al. Determinação da atividade antioxidante total em frutas pela captura do radical livre ABTS. Fortaleza: Embrapa Agroindústria Tropical, 2007a. 4p (Comunicado Técnico, 128), 2007 a.

RUFINO, M. S. M. et al. Determinação da atividade antioxidante total em frutas pela captura do radical livre DPPH. Fortaleza: Embrapa Agroindústria Tropical, 2007b. 4p (Comunicado Técnico, 127), 2007b.

SÁNCHEZ-MORENO, C.; LARRAURI, J. A.; SAURA-CALIXTO, F. A procedure to measure the antiradical efficiency of polyphenols. Journal of the Science of Food and Agriculture, 76(2):270-276, 1998.

SANTOS, A. O.; PEREIRA, S. E.; MOREIRA, C. A. Qualidade físicoquímica da uva e perfil sensorial vínico para diferentes cultivares de videira submetidas à poda mecanizada. Revista Brasileira de Fruticultura, 37(2):432-441, 2015.

SILVA, M. J. R. et al. Grape juice produced from new hybrid varieties grown on Brazilian rootstocks - Bioactive compounds, organic acids and antioxidant capacity. Food Chemistry, 289:714-722, 2019.

SILVA, M. J. R. et al. Yield performance of new juice grape varieties grafted onto different rootstocks under tropical conditions. Scientia Horticulturae, 241(18):194-200, 2018.

SOARES, J. M.; LEÃO, P. C. de S. (Ed.). A vitivinicultura no Semiárido brasileiro. Brasília: Embrapa Informação Tecnológica, 2009. 756p.

VRŠIČ, S.; PULKO, B.; KOCSIS, L. Factors influencing grafting success and compatibility of grape rootstocks. Scientia Horticulturae, 181(2):168-173, 2015.

YEMN, E. W.; WILLIS, A. J. The estimation of carbohydrates in plant extracts by anthrone. The Biochemical Journal, 57(3):508-514, 1954. 